\title{
RESILIENSI PADA LANSIA
}

\author{
Andria Pragholapati ${ }^{1}$, Fitri Munawaroh ${ }^{2}$ \\ ${ }^{1}$ STIKes Jenderal Achmad Yani, Cimahi \\ ${ }^{2}$ STIKes Bhakti Kencana Bandung \\ Email: andria.pragholapati@gmail.com
}

\begin{abstract}
ABSTRAK
Depresi merupakan salah satu penyakit yang banyak terjadi dikalangan lansia. Untuk mengatasi stres, depresi, dan kecemasan dibutuhkan sikap resilien. Setiap individu mempunyai kemampuan untuk tangguh (resilien) secara alami, tetapi hal tersebut harus dipelihara dan diasah. Penelitian ini bertujuan untuk mengetahui gambaran resiliensi pada lansia di Balai Pelindungan Sosial Tresna Wredha Ciparay. Penelitian ini menggunakan metode deskriptif kuantitatif. Populasi dalam penelitian ini adalah lansia di Panti Wredha sebanyak 150 orang. Jumlah sampel dalam penelitian ini sebanyak 60 dengan teknik pengambilan sample slovin. Pengumpulan data menggunakan kuesioner Wagnild \& Young (1993). Analisa yang digunakan adalah analisa univariat. Hasil penelitian menunjukan mayoritas lansia di Balai Perlindungan Sosial Tresna Wredha Ciparay memiliki tingkat resiliensi yang tinggi. Perawat dapat menggunakan hasil penelitian ini untuk mengidentifikasi lansia berisiko tinggi untuk resiliensi rendah.
\end{abstract}

Kata kunci: Resiliensi, Lansia 


\title{
RESILIENCE IN ELDERLY
}

\begin{abstract}
Depression is a disease that often occurs among the elderly. To deal with stress, depression, and anxiety requires a resilient attitude. Every individual has the ability to be resilient naturally, but this must be nurtured and honed. This study aims to determine the picture of resilience in the elderly at the Social Protection Center in Tresna Wredha Ciparay. This research uses quantitative descriptive method. The population in this study is the elderly at the Panti Wredha as many as 150 people. The number of samples in this study were 60 with slovin sampling techniques. Data collection using a questionnaire from Wagnild \& Young (1993). The analysis used is univariate analysis. The results showed that the majority of elderly people at the Tresna Wredha Ciparay Social Protection Center had a high level of resilience. Nurses can use the results of this study to identify elderly people at high risk for low resilience.
\end{abstract}

Keywords: Resilience, Elderly

\section{PENDAHULUAN}

Perubahan adalah suatu proses alamiah yang tidak bisa dihindari dalam kehidupan. Salah satu contoh perubahan yang pasti terjadi pada manusia dapat dilihat dalam rentang kehidupan yang diawali dengan kelahiran, tumbuh, berkembang, menjadi tua dan kemudian mati. Setiap perubahan dalam kehidupan manusia tersebut mendapatkan banyak perhatian khusus dari berbagai macam pihak. Salah satunya ialah orang tua atau yang biasa disebut lanjut usia (lansia). Populasi lansia tiap tahun semakin bertambah banyak (Marmer, 2011). Menurut Undang-undang No. 13 tahun 1998 tentang kesejahteraan lansia, yang dimaksud dengan lansia adalah seseorang baik laki-laki maupun perempuan yang telah berusia 60 tahun atau lebih (Kementrian Sosial RI, 2008). Tahun 2015 dan 2050, proporsi lansia di dunia diperkirakan hampir dua kali lipat dari sekitar $12 \%$ sampai $22 \%$. Secara absolut, ini merupakan peningkatan dari 900 juta sampai 2 miliar orang lansia (World Health Organization, 2016).

Asia dan Indonesia dari tahun 1990 dan 2000 memiliki jumlah penduduk <15 tahun lebih besar dari penduduk lansia (>60 tahun), tetapi pada tahun 2040 baik global atau dunia, asia dan Indonesia diprediksikan jumlah penduduk lansia sudah lebih besar dari jumlah penduduk <15 tahun. Sebaran penduduk lansia mencatat populasi lansia golongan umur 60 tahun ke atas di provinsi Jawa Barat, terdiri dari 2.739.719. (7,05\%) jiwa dari 38.886.975 jiwa total penduduk Jawa Barat, terdiri dari $1.394 .583 \quad(50,9 \%)$ jiwa lansia laki-laki dan 1.345.136 $(49,09 \%)$ jiwa lansia perempuan (Badan Pusat Statistik, 2013). 
Menurut Maramis (2011) proses penuaan secara alamiah dapat menimbulkan beberapa perubahan meliputi perubahan fisik, psikologis, social, bahkan spiritual. Proses adaptasi terhadap perubahan serta stress lingkungan sering menyebabkan gangguan mental pada lansia. Banyak lansia kehilangan kemampuan mereka untuk hidup mandiri karena keterbatasan mobilitas, sakit kronis, kelemahan atau masalah mental atau fisik lainnya, dan memerlukan beberapa bentuk perawatan jangka panjang. Selain itu, lansia lebih cenderung mengalami kejadian seperti berkabung, turun status sosio-ekonomi dengan masa pensiun, atau cacat. Semua faktor ini dapat berakibat pada kesehatan jiwa lansia yaitu ansietas, demensia, delirium, kesepian, dan depresi (Stanly $\&$ Beare, 2006).

Depresi adalah satu masa terganggunya fungsi manusia yang berkaitan dengan alam perasaan yang sedih dan gejala penyertanya, termasuk perubhan pada pola tidur dan nafsu makan, psikomotor, konsentrasi, anhedonia, kelelahan, rasa putus asa dan tidak berdaya, serta bunuh diri (Kaplan, 2011). Prevalensi depresi pada lansia cukup tinggi hampir 350 juta penduduk di dunia tahun 2010, berkisar antara $12-36 \%$ lansia yang mengalami depresi yaitu sekitar 7 juta dari 39 juta jiwa. Gejala depresi pada lansia sering diabaikan dan tidak diobati karena bertepatan dengan masalah lain yang dihadapi oleh lansia (World Health Organization, 2016). Data prevalensi depresi pada lansia di Indonesia cukup tinggi. Berdasarkan penelitian kesehatan Universitas
Indonesia dan Oxford Institute of aging menunjukkan bahwa 30\% dari jumlah lansia di Indonesia mengalami depresi (Komnas lansia, 2016).

Untuk mengatasi stres, depresi, dan kecemasan dibutuhkan sikap resilien. Setiap individu mempunyai kemampuan untuk tangguh (resilien) secara alami, tetapi hal tersebut harus dipelihara dan diasah. Jika tidak dipelihara, maka kemampuan tersebut akan hilang (Masten \& O'CONNOR, 1989). Perkembangan resiliensi dalam kehidupan akan membuat individu mampu mengatasi stres, trauma dan masalah lainnya dalam proses kehidupan dan merupakan salah satu bentuk kesadaran seseorang untuk mengubah pola pikir dalam menghadapi permasalahan sehingga tidak mudah putus asa sehingga individu dapat beradaptasi dengan menempatkan diri dengan baik terhadap pengalaman yang tidak menyenangkan (Aroian \& Norris, 2000; Choowattanapakorn et al., 2010; Foster, 1997; García-León et al., 2019; $\mathrm{PhD}$ et al., 2004; Richardson, 2002; Wagnild \& Young, 1993).

Ciri-ciri individu yang memiliki resiliensi menurut Sarafino (1994), adalah (a) memiliki temperamen yang lebih tenang, sehingga dapat menciptakan hubungan yang lebih baik dengan keluarga dan lingkungannya; (b) Individu yang memiliki resiliensi juga memiliki kemampuan untuk dapat bangkit dari tekanan, stres, dan depresi. Untuk mengatasi tekanan, stres, dan depresi dibutuhkan ketiga komponen resiliensi. Ketiga komponen dalam resiliensi tersebut adalah: pertama, 'I have', berkaitan dengan sumber daya 
yang dimiliki. Kedua, 'I am', berkaitan dengan konsep diri dan integritas pribadi. Ketiga, 'I can', berkaitan dengan kapabilitas, kemampuan, dan self efficacy. Penelitian ini bertujuan untuk mengetahui resiliensi pada lansia di BPSTW Ciparay.

\section{METODE PENELITIAN}

Rancangan penelitian menggunakan penelitian deskriptif. Tujuan penelitian ini adalah mengetahui Gambaran Resiliensi pada lansia di Balai Perlindungan Sosial Tresna Werdha Ciparay Kabupaten Bandung. Sample dalam penelitian ini sebanyak 60 responden. Kuesioner menggunakan Lembar Cheklist, yaitu daftar isian yang telah dipersiapkan terlebih dahulu sebelum penelitian dimulai. Pengisian lembar Cheklist dengan cara pengukuran Skala Resiliensi. Skala resiliensi dari Wagnild \& Young (1993). Skala resiliensi berupa kumpulan pernyataan-pernyataan mengenai kemampuan untuk bertahan, beradaptasi terhadap sesuatu yang menekan, mampu mengatasi dan melalui, serta mampu untuk pulih kembali dari keterpurukan. Pada item favourable skor bergerak dari angka 1 untuk pernyataan sangat tidak setuju (STS), skor 2 untuk tidak setuju (TS), skor 3 untuk setuju (S), dan skor 4 untuk sangat tidak setuju (SS). Rentang skor resiliensi rendah 21-42, sedang 4263, tinggi 63-84. Uji validitas dilakukan pada 20 orang didapatkan dari $r$ product moment dengan $\alpha=5 \%$. Berdasarkan hasil perhitungan uji reliabilitas, dari 21 pertanyaan dalam variabel resiliensi adalah reliable karena koefisien lebih besar dari pada nilai kritisnya yaitu 0,6 $(0,918>0,6)$. Uji etik penelitian dilakukan melalui komite etik dan sudah disetujui sesuai dengan kaidah etik, seperti data klien bersifat rahasia, tanpa nama, menggunakan kode, tidak merugikan, dan tidak membahayakan, tidak menimbulkan efek negatif, dan menjelaskan prosedur, manfaat kepada klien dan dilakukan persetujuan klien sebelum dilakukan penelitian.

\section{HASIL}

\section{Tabel 1}

Distribusi Frekuensi Resiliensi pada lansia di Balai Perlindungan Sosial Tresna Wredha Ciparay

\begin{tabular}{cccc}
\hline No & Resiliensi & Frekuensi & Persentase \\
\hline 1. & Rendah & 0 & $0,0 \%$ \\
2. & Sedang & 22 & $36,7 \%$ \\
3. & Tinggi & 38 & $63,3 \%$ \\
\hline & Jumah & 60 & $100 \%$ \\
\hline
\end{tabular}

Dari tabel 1 di atas menunjukan dari 60 orang lansia di Balai Perlindungan Sosial Tresna Wredha
Ciparay yang memiliki resiliensi rendah tidak ada, yang memiliki resiliensi sedang berjumlah 22 orang dengan 
persentase $36,7 \%$ dan yang memiliki resiliensi tinggi sejumlah 38 orang dengan persentase $63,3 \%$.

\section{PEMBAHASAN}

60 orang lansia di Balai Perlindungan Sosial Tresna Wredha Ciparay yang memiliki resiliensi rendah tidak ada, yang memiliki resiliensi sedang berjumlah 22 orang dengan persentase $36,7 \%$ dan yang memiliki resiliensi tinggi sejumlah 38 orang dengan persentase $63,3 \%$. Hal ini menunjukkan bahwa Lansia di Balai Perlindungan Sosial Tresna Wredha Ciparay memiliki kemampuan individu yang baik dalam mengatasi masalah, kekecewaan dan trauma yang dihadapi.

Resiliensi merupakan kemampuan untuk mengatasi rasa frustasi dan permasalahan yang dialami oleh individu. Individu yang resilien akan berusaha untuk mengatasi permasalahan dalam hidup, sehingga dapat terbebas dari masalah dan mampu beradaptasi terhadap permasalahan tersebut (García-León et al., 2019). Resiliensi merupakan suatu kemampuan yang dimiliki oleh individu untuk segera membebaskan diri dari kondisi yang kurang menyenangkan (Seligowski et al., 2020).

$$
\text { Resiliensi merupakan }
$$

kemampuan untuk bertahan, beradaptasi terhadap sesuatu yang menekan, mampu mengatasi dan melalui, serta mampu untuk pulih kembali dari keterpurukan (Wagnild \& Young, 1993). Resiliensi pada lansia merupakan kemampuan beradaptasi dan mengatasi masalah yang dihadapi lansia (Brockie \& Miller, 2017). Lansia yang memiliki resiliensi tinggi memiliki kesehatan mental yang baik, kepribadian yang cukup stabil, memiliki penyesuaian psikososial yang baik, bahkan kemampuan kognitif (memori dan kecerdasan) relatif berfungsi dengan baik selama di usia tua (Foster, 1997).

Konsep resiliensi bukanlah hal baru, meskipun penelitian baru-baru ini berkembang di bidang ini. Di Bahkan, lebih dari $85 \%$ dari semua publikasi penelitian tentang resiliensitelah muncul dalam dekade terakhir (Hjemdal, 2007). Penelitian tentang resiliensi berfokus pada identifikasi kualitas-kualitas tertentu dan ciri-ciri kepribadian, seperti sifat tahan banting dan self-efficacy, yang membantu orang untuk mengatasi kesulitan (Cicchetti \& Garmezy, 1993). Penelitian yang lebih baru telah difokuskan pada proses dimana kualitas resiliensi diperoleh waktu dan fluktuasi alami yang terjadi sepanjang hidup. Yang terakhir mungkin tergantung pada keseimbangan stress, faktor pelindung dan kompensasi. Baru-baru ini penelitian telah menyebabkan perubahan pandangan dominan tentang resiliensi dari kualitas bawaan atau yang diwariskan ke kualitas lebih dinamis, kontekstual, dan didapat. Konferensi baru-baru ini peneliti resiliensi mendefinisikan resiliensi sebagai proses dinamis di mana faktor-faktor psikologis, sosial, lingkungan, dan biologis berinteraksi untuk membuat seorang individu, pada setiap tahapan hidup, untuk mengembangkan, mempertahankan atau mendapatkan kembali kesehatan mental mereka dalam kesulitan (WHO $\mid$ Preventing violence across the lifespan research 
network (PreVAiL), n.d.). Konseptualisasi resiliensi yang lebih baru melihatnya sebagai proses dinamis interaktif yang berkembang melalui proses gangguan dan reintegrasi yang berulang dalam respons untuk kejadian buruk (Richardson, 2002). Melalui proses ini, diduga bahwa faktor-faktor perlindungan psikologis itu memfasilitasi adaptasi positif untuk kehidupan buruk selanjutnya peristiwa berkembang, dengan demikian mempromosikan kesehatan mental yang positif, yang mungkin bertambah dan menyusut sepanjang umur. Berhasil adaptasi ke kehidupan selanjutnya membutuhkan resiliensi ini untuk menghadapi berbagai tantangan tahap kehidupan yang hampir tak terhindarkan seperti yang terkait dengan kesehatan, keadaan sosial ekonomi, hubungan, dan status pekerjaan. Penelitian sebelumnya menunjukkan bahwa banyak lansia memandang diri mereka sebagai telah berhasil menua, meskipun ada penyakit kronis dan kecacatan (Depp et al., 2010; Foster, 1997).

Faktor yang mempengaruhi tingginya resiliensi Lansia di Balai Perlindungan Sosial Tresna Wredha Ciparay yaitu pernyataan Saya dapat mengontrol perilaku (perasaan, dorongan dan tindakan). Hal ini menunjukkan beberapa Lansia selama Balai Perlindungan Sosial Tresna Wredha Ciparay mengalami perubahan sehingga dapat mengontrol perilaku sehari-hari.

\section{KESIMPULAN}

Mayoritas lansia di Balai Perlindungan Sosial Tresna Wredha
Ciparay memiliki tingkat memiliki resiliensi sedang berjumlah 22 orang dan yang memiliki resiliensi tinggi sejumlah 38 orang dan tidak ada satupun lansia yang memiliki resilensi rendah.

\section{SARAN}

Perawat dapat menggunakan hasil penelitian ini untuk mengidentifikasi lansia berisiko tinggi untuk resiliensi rendah dan merancang intervensi khusus untuk mempromosikan hasil kesehatan yang lebih baik.

\section{UCAPAN TERIMAKASIH}

Pada kesempatan ini, peneliti ingin mengucapkan terima kasih kepada berbagai pihak yang telah membantu mewujudkan penelitian ini :

1. STIKES Jenderal Achmad Yani Cimahi

2. STIKES Bhakti Kencana Bandung

\section{DAFTAR PUSTAKA}

Aroian, K. J., \& Norris, A. E. (2000).

Resilience, stress, and depression among Russian immigrants to Israel. Western Journal of Nursing Research, 22(1), 54-67.

Brockie, L., \& Miller, E. (2017). Understanding older adults' resilience during the Brisbane floods: Social capital, life experience, and optimism. Disaster Medicine and Public 
Health Preparedness, 11(1), 7279.

Choowattanapakorn, T., Aléx, L., Lundman, B., Norberg, A., \& Nygren, B. (2010). Research Article: Resilience among women and men aged 60 years and over in Sweden and in Thailand. Nursing \& Health Sciences, 12(3), 329-335. https://doi.org/10.1111/j.14422018.2010.00534.x

Cicchetti, D., \& Garmezy, N. (1993). Prospects and promises in the study of resilience. Development and Psychopathology, 5(4), 497-502.

Depp, C., Vahia, I. V., \& Jeste, D. (2010). Successful aging: Focus on cognitive and emotional health. Annual Review of Clinical Psychology, 6, 527550.

Foster, J. R. (1997). Successful coping, adaptation and resilience in the elderly: An interpretation of epidemiologic data. Psychiatric Quarterly, 68(3), 189-219.

García-León, M. Á., Pérez-Mármol, J. M., Gonzalez-Pérez, R., GarcíaRíos, M. del C., \& PeraltaRamírez, M. I. (2019).

Relationship between resilience and stress: Perceived stress, stressful life events, HPA axis response during a stressful task and hair cortisol. Physiology \& Behavior, 202, 87-93. https://doi.org/10.1016/j.physbe h.2019.02.001

Hjemdal, O. (2007). Measuring protective factors: The development of two resilience scales in Norway. Child and Adolescent Psychiatric Clinics of North America, 16(2), 303321.

Masten, A. S., \& O'CONNOR, M. J. (1989). Vulnerability, stress, and resilience in the early development of a high risk child. Journal of the American Academy of Child \& Adolescent Psychiatry, 28(2), 274-278.

PhD, R. R. G., DSW, C. G., \& DSW, Y. L. (2004). Resilience Theory. Journal of Human Behavior in the Social Environment, 8(4), 75-91. https://doi.org/10.1300/J137v08 n04_05

Richardson, G. E. (2002). The metatheory of resilience and resiliency. Journal of Clinical Psychology, 58(3), 307-321.

Seligowski, A. V., Hill, S. B., King, C. D., Wingo, A. P., \& Ressler, K. J. (2020). Chapter 10 Understanding resilience: Biological approaches in at-risk populations. In A. Chen (Ed.), Stress Resilience (pp. 133-148). Academic Press. https://doi.org/10.1016/B978-012-813983-7.00010-0

Stanly, M., \& Beare, P. G. (2006). Buku ajar keperawatan gerontik.

Wagnild, G. M., \& Young, H. M. (1993). Development and psychometric evaluation of the Resilience Scale. Journal of Nursing Measurement, 1(2), 165-178. 
WHO $\mid$ Preventing violence across the lifespan research network (PreVAiL). (n.d.). WHO.

Retrieved January 22, 2020, from

https://www.who.int/violencepre vention/participants/prevail/en/ 